DOI https://doi.org/10.18551/rjoas.2016-12.11

\title{
PUBLIC PARTICIPATION IN BUDGETING PROCESS AT LOCAL GOVERNMENT IN INDONESIA
}

\author{
Domai Tjahjanulin \\ Faculty of Administrative Science, University of Brawijaya, Indonesia \\ E-mail: lugman.academia@gmail.com
}

\begin{abstract}
Bearing in mind that public participation is not only needed in the execution stage, but also in the stage of planning and decision making, this study describes the public involvement (poor fisherman community) in the budgeting process of a local government in a regency in Eastern Java region, Indonesia, and all of obstacles that might be found in the optimization of public participation in the budgeting process. The research is qualitative by using descriptive analytical approach. The findings shows that public participation (fisherman community) still have not been involved directly in the budgeting process. The obstacle encountered at the execution of participation forum in the event of budgeting process is the time discrepancy of the budgeting process execution between the local government and society (fishing communities), the time constraints of fishermen in following the execution of the budgeting process, lack of knowledge, the apathy of the community, and the phenomenon of bicameral planning and budgeting, which are the dichotomizing between the two areas of authority.
\end{abstract}

\section{KEY WORDS}

Public participation, budgeting, planning, local government.

Budgeting literary can be translated into public budget (local budget and state budget), it is one of the products of government's work which is administrative and routine. State budget and local budget are only seen as a written document containing income and expenditures of a government (state and local). It is like as proposed by BIGG (Building Institutions for Good Governance (2004) which means that public budget is a plan of Government's revenue and expenditure (local and or state) allocated to fund the provision of services to the public. The budget also contains an overview where the money come from and how it will be used, and also various services that will be served. In the context that is more comprehensive, public budget has to be interpreted as a reflection of the drop pulled of power relation and interest relation between the institutional actors in a country or region. Those actors are market players (private sector), non-government organization, and other parties concerned, Political Party, civil society, as well as state officials which in this case is personified by the executive and legislative officials.

A current phenomenon occurred is practicing planning and development budgeting that still uses old version rule. Public participation is not become a routine and institutionalized activity yet, especially in the process of public policy formulation. The minimum public participation condition is more worrying occurred in poor communities, including small fishing communities. This pattern is precisely contrary to the spirit of participation, namely to put forward bottom-up mechanism (Paskarina, 2005). Budgeting issues and public participation are very strategic matter in the process of public policy formulation. Berner (2001) proposed that public participation in the government process becomes the key to the formulation of public policies related to the budget preparation process.

Relying on the spirit of participatory budgeting, thus there must be a real effort to involve society (especially the target group) in the process of formulating the program and budget preparation. In the context of empowerment of small fishermen, it should be prioritized to formulate empowerment programs that really useful. It is absolutely necessary in order the construct of the program and the number of budget allocated really fit to the needs of the target audience. Based on the description above, so that how the public 
involvement in the budgeting process as well as what the obstacles that is found in the field during the budgeting process undertaken by local authorities.

\section{LITERATURE REVIEW}

Public Participation. The more complete meaning of participation was proposed by Charly as quoted by Talizuduhu (1922), in which participation is the involvement of mental and emotional of person or group of society in a community that encourage the concerned one on his/her own will according to the ability of expense to take part in achieving the common goal in accountability. To be able to grow and thrive, public participation in development requires prerequisites or elements of participation. Kotler mentioned several elements/prerequisite of participation always found in every development, namely the purpose, change agent, and change targets.

Participatory budgeting. Participatory budgeting is a creative innovation in policymaking processes, especially in the public budgeting process. In the process of participatory budgeting, public will be directly involved in policy-making. According to Wampler (2000), budgeting process was designed so as with public involvement in the policy-making process, encouraging administrative reform, and distributing public resources to the community, especially living in low-income neighborhoods. Residents with the low-income levels usually are outside the traditional political system, now they have an opportunity to be involved in policy-making.

\section{Participants}

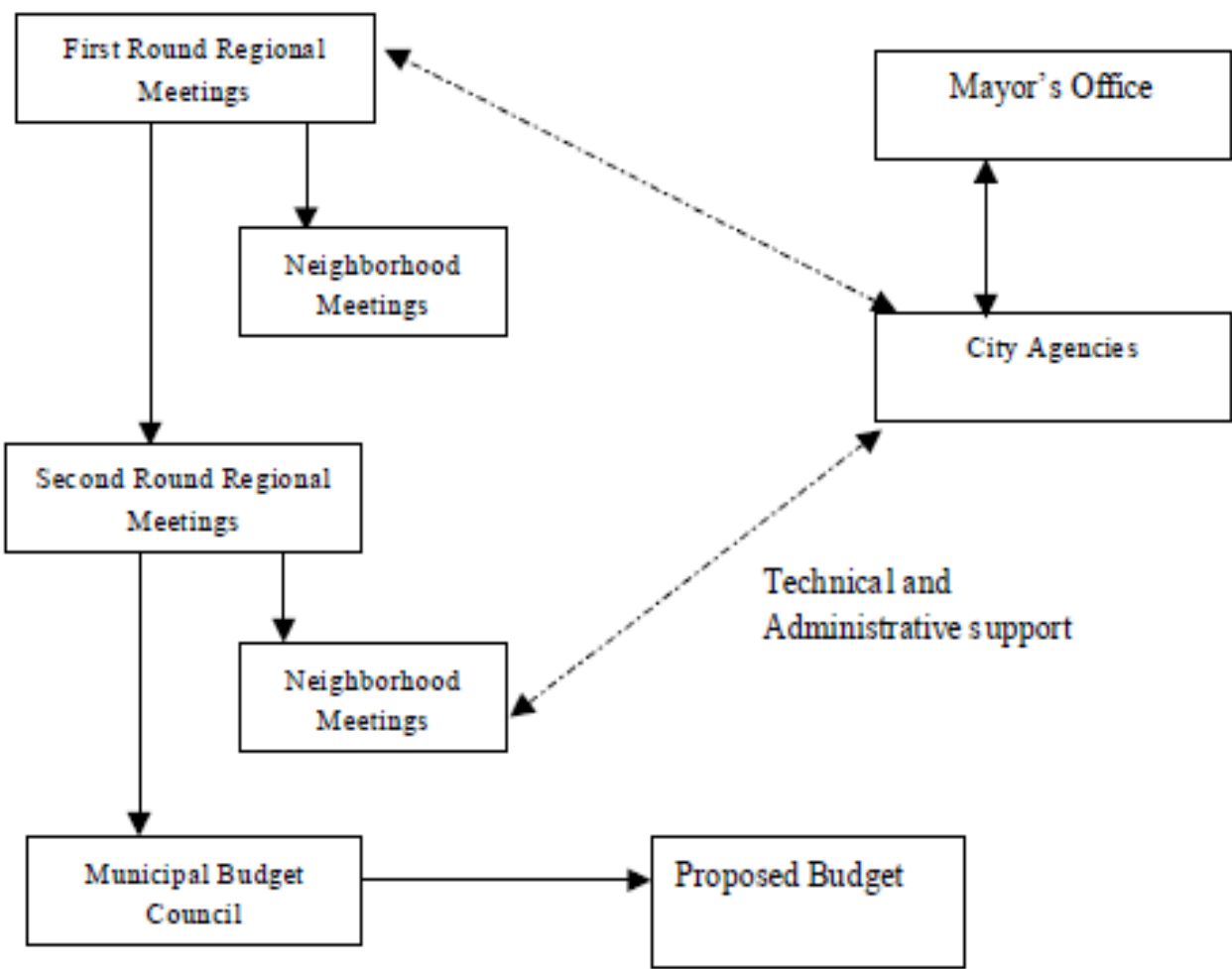

Figure 1 - Yearly Participatory Budgeting Cycle (Source: Adopted from Wampler, 2000)

The Urgency of Participatory Preparation. The discourse on public participation in the preparation and management of public sector actually has received long attention. Samsura said (2003) that in America, this discourse appeared since the late of 1950s, while in the UK 
since the early 1960s, and Australia followed in 1970. This discourse is expanding in line with the changes of political structure that leads to a system known as democracy. This democratization process at a time will encourage the formation of a civil society in which giving room that is spacious enough for people to participate in public decision making process. The experience in many countries shows the need of the civil society organization's role, included Non-Governmental Organization (NGO) in encouraging the participatory development process. The role is particularly in terms of introducing and practicing the participatory development approach to the public.

Followed by Adriansyah (2003), these NGOs also play a role in efforts to increase awareness of the importance of community participation in public decision making process as well as advocacy for policy reform to make it more conducive to community participation. According to Berner (2001), there are at least two main objectives to be achieved by involving the public in decision making process conducted by the government, namely, (1) to inform the public of government decisions and (2) to involve the public in government decision making.

Involving the public in their turn can minimize distrust of the public to the government, and it can also be used as a medium of learning for citizens on the activities of the government. In connection with the preparation of Budgeting, BIGG (2005) suggested that local governments should make Budgeting guideline for public. The purpose of this effort is to provide understandable picture of the resources owned by the local government as well as how these resources will be utilized in the budget that has been approved. For that reason, the guideline will provide "real picture" of the current priorities and also can be used as one of the best ways to communicate and receive feedback from the public.

\section{METHODS OF RESEARCH}

The current research was qualitative research by using descriptive analysis approach. Here, the researcher attempted to obtain in-depth picture of the intensity of public participation, especially the poor fisherman communities, in the budgeting process of Trenggalek Regency's local budget, a city located in Eastern Java region, Indonesia. Furthermore, the findings were critically analyzed, both were relying on empirical rules based analyzes and theoretical based analyzes. Miles \& Huberman (1992) stated that in qualitative analysis, data appeared in the form of words not a series of numbers. Basically, there were three main components in qualitative research (Strauss \& Corbin, 1990). The first was the data that could be obtained from various sources, interviews, and observation. The second was the ones consisting of the analysis or different interpretation procedures in order to obtain findings or theories. The third one consisted of writing and verbal reports.

\section{FINDINGS AND DISCUSSION}

The application of the principles of Participatory Budgeting in Indonesia is implemented through the organizing of Regional Development Planning Forums (Musyawarah Rencana Pembangunan or Musrenbang) with the participants who are actively involved in Musrenbang; they are (1) Provincial Administrations; (2) Regional Legislative Council (DPRD); (3) Society; (4) Voluntary Organization; and (5) Non-Government Organization.

The participation of the Provincial Administrations is represented by the government at the village level to the district, which in this case is the Government of Tasikmadu Village, Watulimo District, the Local Maritime Affairs and Fisheries Agency (DKP), Watulimo Development and Planning Agency (Bappekab), and several departments or other relevant agencies. Meanwhile, the involvement of society in the execution of Regional Development Planning Forums (Musrenbang) is not directly held by each of community. They are usually represented by the head of the neighborhood, such as head of neighborhood units, community units, and a village chief as well as a public figure in the region prigi beach and other surroundings. 
The participation of voluntary organization in the forum of participatory budgeting is represented by Fishermen communities; such as Purse Siene Fishermen Community, Payang Fishermen Community, Jaring Tarik Fisherman Community, and others. Even though public are involved in the planning process through Regional Development Planning Forums (Musrenbang), but this involvement is often just a formality because there is no guarantee that public input at the village level is used as an important reference in preparing local budget. On finalizing stage of the planning program (as a base of budgeting) public aspirations often had to yield to the local administration's working unit (SKPD) that is normally in the name of the strategic planning (renstra), Mid-Term Development Plan (RPJM), city working plan (RKPD) and also budget constraints. The direct involvement of Civil Society in the participatory budgeting process is limited in the first round of Regional Development Planning Forums. Even then, more citizen involvement is represented by a public figure, head of the local environment, the chairman of the group of fishermen, or other local elites.

Commonly, fisherman does not have enough time to participate in social activities in land. They spends their time to conduct fishing activity as well as other activities related to fishing; (2) The education lack; the educational level of fisherman are commonly low (on average they just elementary school graduation, or even most of them are not graduate) their knowledge on development and budgeting are also minimum; (3) apathy among societies. The level of education and living conditions of low socio economic causes less people show their concern matters that are not directly relevant to the development of life. They consider that the presence in the participatory forum is nothing more than a waste of time; (4) The timing is not right. Participatory forums are generally held at night, whereas most of the the fishermen go out to sea at night; (5) bicameral planning and budgeting. In the Regional Development Planning Forums, things that usually appear are proposed development programs of a general thing (such as the repair of roads, bridges, irrigation, etc.). Meanwhile, the proposed programs related to Marine and Fisheries, by the chief of the village, are directed to be delivered to Department of Marine and Fisheries.

\section{CONCLUSION}

Based on the findings of the research, it is concluded that the obstacles encountered at the execution of participation forum in the event of budgeting process comprise the time discrepancy of the budgeting process execution between the local government and society (fishing communities), the time constraints of fishermen in following the execution of the budgeting process, lack of knowledge, the apathy of the community, and the phenomenon of bicameral planning and budgeting, which are the dichotomizing between the two areas of authority.

\section{REFERENCES}

1. Berner, M. (2001). Citizen Participation in Local Government Budgeting. Popular Government article by Spring.

2. BIGG. (2005). Panduan Penyusunan Pedoman Penganggaran Bagi Masyarakat. Published by Building Institutions for Good Governance (BIGG), www.bigg.or.id.

3. Dendi, A., \& Roesman, A. (2005). Mengembangkan Perencanaan Dan Penganggaran Partisipatif Di Daerah: Pengalaman dam Perspektif GTZ PROMIS-NT Nusa Tenggara. Paper presented in Forum Regional/ Forum Nasional FPPM, Lombok, Indonesia.

4. Indrayana, P.A. (2004). Draft Position Paper: Kerangka Penganggaran Partisipatif. Bandung Institute for Governance Studies (BIGS). Bandung

5. Kathlene, L. \& Martin, J.A. (1991). Enhancing Citizen Participation: Panel Designs, Perspectives, and Policy Formation. Journal of Policy Analysis and Management 10 (1).

6. Krafchik, W. (2001). Can civil society add value to budget decision-making? A description of civil society budget work. International Budget Project. 
7. Loimann, K.O. (2003). Community Participation in the Planning and Management of Marine Protected Areas: A Study Of Kenya and the Philippines, Fulfillment Of the Requirements for the Degree of Bachelor of Arts with Honors in International Relations, Brown University Providence, Rhode Island.

8. Miles, B.M. \& Huberman, A.M. (1992). Analisa Data Kualitatif. UI-Press. Jakarta.

9. Notowidagdo, S.H. (1982). Metodologi Research. Fakultas Fsikologi UGM, Yogyakarta.

10. Paskarina, C. (2005). Perencanaan Partisipatif: Model Alternatif Dalam Pembangunan Daerah. www.jurnal-kopertis4.org.

11. Samsura, A. (2003). Participatory Planning, Good Governance, and Civil Society. Article of Participatory Planning.

12. Strauss, A. \& Corbin, J. (1992). Basic of Qualitative Research, Grounded Theory, Procedures and Techniques. Sage Publications, New Bury Park, California.

13. Suhirman \& Haryadi, D. (2001). Distorsi Proses Anggaran Dan Penguatan Masyarakat Sipil, Paper from Seminar Internasional II mengenai Dinamika Politik Lokal yang diselenggarakan oleh Yayasan Percik, Yayasan Riau Mandiri dan Ford Foundation.

14. Talizuduhu, N. (1992). Partisipasi Masyarakat Desa dalam Pembangunan Pedesaan di beberapa Desa. Yayasan Karya Darma. Jakarta.

15. Wampler, B. (2000). A Guide to Participatory Budgeting. World Bank. 